SŪN MÈNGYÁO

Liaocheng University

1310543954@qq.com

MICHAEL KNÜPPEL

Liaocheng University

michaelknueppel@gmx.net

\title{
ON CHINESE HUI-MUSLIM ELEMENTARY VOCABULARY (1): PRAYER TERMINOLOGY
}

Keywords: Hui Muslims; Sino-Arabic and Sino-Persian transcriptions; direct and indirect loans; Muslim prayer terminology

\begin{abstract}
In the article, which forms the first part of a series on Chinese Hui-Muslim religious terminology, the authors are dealing with the Hui Muslim prayer terminology, that can roughly be divided into direct and indirect loans. While the direct loans are borrowings from Arabic or Persian, the indirect loans are formed by the means of the own languages (so-called calques).
\end{abstract}

I.

In most Chinese dictionaries compiled in China as well as in the West the specific elementary vocabulary of Islam is omitted although the Chinese Hui Muslims are using it and have even coined some terms used only by them. In some cases common Chinese words are used in the context of Islam but they are not designated as Muslim terminology in the respective compendia. In this article, which forms the first part of a series of papers on Chinese Muslim elementary vocabulary, the writers

1 The present paper results from some fieldwork in the context of socio-linguistic research on the Hui-Muslim communities in the province of Shāndōng in 2018 and 2019. 
give a short overview of those terms used in the context of the prayer and performing prayers among China's Hui Muslims.

The terms can be differentiated to (1) direct borrowings in Sino-Arabic and (in few cases) Sino-Persian transcription (Arabic and Persian loanwords phonetically transcribed with Chinese characters), (2) indirect borrowings or words and phrases formed by the Hui with Chinese elements to describe the material or spiritual aspects of Muslim prayers or related to prayers, and (3) common Chinese words used by the Hui in a specific Muslims context. In some cases Sino-Arabic and Sino-Persian terms as well as originally Chinese terms can describe the same item, issue, concept, idea, etc. The terminology also has to be explained on the one hand, in terms of specific Hui Muslim use and on the other hand, considering the current situation of the community that forms an official "nationality" in the People's Republic of China.

II.

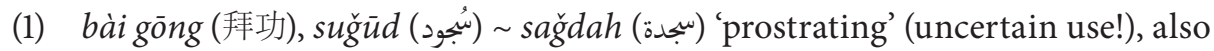
used to name the formula 'alayhi s-salām (عليه السلام) ('peace be upon him').

(2) bāng dá (邦答), the first daily prayer = Sino-Persian transcription of بامداد; see also $\rightarrow$ chén lǐ (晨礼).

(3) bān kè (班克) $\rightarrow x u \bar{a} n$ lĭ cí (宣礼词).

(4) bū lù (晡礼) 'before sunset' - (șalāt) al-c așr (العصر), the third daily prayer ('prayer before the sunset’); see also $\rightarrow$ dù gài léi (底盖雷) d d̆ gài lei (底盖嘞).

(5) chén lù (晨礼) ‘before dawn’ rì chū tóu (日出头) fú xiăo (拂晓), (șalāt) al-fağr (الفجر), the first daily prayer ('prayer before daybreak'), the last one again is a Sino-Arabic transcription; see also $\rightarrow$ bāng dá (邦答).

(6) dà zàn cí (大赞词), takbìr ( تَّic), the name of the Arabic phrase to praise / glorify

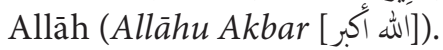

(7) dĭgài lei (底盖嘞) $\rightarrow$ dĭgài léi (底盖雷).

(8) d̆̉ gài léi (底盖雷) ${ }^{2} \sim$ d̆ gài lei (底盖嘞), ${ }^{3}$ the third daily prayer = Sino-Persian transcription of ديكن; see also $\rightarrow b \bar{u} l \breve{l}$ (晡礼).

(9) ĕr dài jié (尔代节), ${ }^{c} \bar{\imath} d$ prayer (عيد) also: șalāt al- ${ }^{c} \bar{\imath} d($ (صلاة العيد) șalāt al-cīdaīn

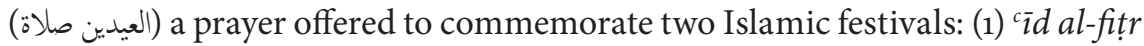

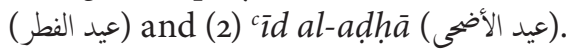

(10) fú xiăo (拂晓) $\rightarrow$ chén lŭ (晨礼).

(11) fù zhŭ ming bài (副主命拜), wāğib prayer (واجب) = obligatory prayer; see also $\rightarrow$ zhŭ ming bài (主命拜).

(12) gĕi bù lái (给布来) 'qibla(-wall) (in the mosque)' = Sino-Arabic transcription of Arabic qibla(-wall) (قب) id.

2 Sino-Persian form noted on the board for prayer times in the Hēi zhuāng-mosque of Línqieng.

3 Given as Sino-Persian form for the prayer on the board for prayer times in the East-mosque of Línqing. 
(13) hăi tuī bù (海推布) 'preacher (in the mosque)' = Sino-Arabic transcription of hațīb (خطي) id.

(14) hŭ fū nán (虎夫难) $\rightarrow$ hú fū tān (湖夫滩).

(15) hú fū tān (湖夫滩) ${ }^{4} \sim$ hŭ fü nán (虎夫难), ${ }^{5}$ the fifth daily prayer = Sino-Persian transcription of ختخ; see also $\rightarrow$ xiāo lŭ (宵礼).

(16) hūn lŭ (昏礼) from the sunset to the sunset has completely disappeared - (șalāt) al-magrib (المغرب), the fourth daily prayer ('prayer at dusk'); see also $\rightarrow$ shā mì (沙目).

(17) hú tŭ bài (胡土拜) 'preaching/sermon' = Sino-Arabic transcription of Arabic hutba (خطبة) id.

(18) jiàn xiē bài (间歇拜), tarāwìh prayer (تراويح), an optional prayer that can be performed during Ramaḍān only.

(19) jiào bài lóu (叫拜楼) $\rightarrow$ wàng yuè lóu (望月楼).

(20) jī shù bài (奇数拜) yè jiān lĭ (夜间礼), witr prayer (وتر) performed in the night after ${ }^{c} i \bar{s}^{\prime}{ }^{\prime}$ (as night-time prayer) or before fağ $r$ (as dawn prayer).

(21) jū $g \bar{o} n g($ 鞠躬 $)=r a k^{c} a h(ر$ ), prayer unit, a single complete part of the daily ritual prayer.

(22) jù lù mù (聚礼目) 'call for prayer ('Adēn; أََذان)'. The call is performed in Arabic language only. The sources of information do not know any Sino-Arabic term for this.

(23) kŏng jù bài (恐惧拜), hawf prayer (خوف), a prayer that is performed during time of fear or being in danger.

(24) lì bài (礼拜) 'prayer', the common Chinese word for prayer used by Hui Muslims for Islamic prayers, too. Other Chinese terms for 'prayer' (dǎo gào [祷告], qí dǎo [祈祷], and qí dǎo wén [祈祷文]) seem not to be in use among Hui Muslims. No Sino-Arabic transcription for Arabic صلاة could be given by the sources of information. For the five daily prayers there are no fixed times, they are related to the position of the sun as in all Muslim societies. In many mosques there is no seperate area for women. Because of this, there is also no term for such a womens' corner. The women pray either at home (e.g. in Shāndōng) or in some special cases have a corner separated by a veil (like in the East-mosque of Liáochéng, which is used by female members of the community who are from Gānsù or Qinghǎi). In few cases the communities have their own mosques for women only (as in Línqīng or Shánghǎi).

(25) lĭ bài tăn (礼拜毯) 'carpet (for prayer)'. Hui Muslims seem to use this term for the carpet for prayer only, although there are other words for this in Chinese

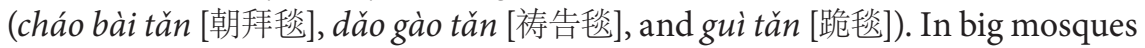
nearly the complete prayer hall is covered with carpets, while in the countryside there often is a limited space in the mosque covered with them and it is only

\footnotetext{
Sino-Persian form written on the board for prayer times in the Hēi zhuāng-mosque of Línqing. Given as Sino-Persian form for the prayer on the board for prayer times in the East-mosque of Línqing.
} 
forbidden to wear shoes on the carpets while in big mosques commonly shoes have to be removed before entering the prayer hall.

(26) lĭng bài shī (领拜师) 'muezzin' (< Arabic mu’addin [مؤذن]). The Hui Muslim communities mostly have no muezzin as a specific position held by one member of the community. Usually the Āhōng himself is performing the call for prayer, sometimes another member who only has to be able to pronounce the Arabic formula in its correct way is doing this. In some cases the recorded prayer call is played from a tape.

(27) lüx xíng bài (旅行拜), journey prayer, that is spoken either before or after a journey.

(28) mŭ hé lā bù (米河啦布) 'miḥrāb (the niche in the qibla-wall)' = Sino-Arabic transcription of Arabic mihrāb (محراب) id.

(29) mìn à lā bó (敏阿拉伯) $\rightarrow$ wàng yuè lóu (望月楼).

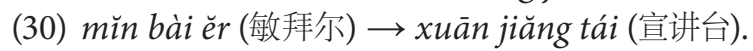

(31) qìng hè bài (庆贺拜), tahiyat al-masǧid (تحية المسجد), prayer for greeting the mosque. It is prayed only when someone enters the mosque prayer hall and intends to sit for praying there.

(32) rì chū bài (日出拜), išrāq prayer (إشراق), is a nafl prayer which is performed about 12 minutes after sunrise.

(33) rì chū tóu (日出头) $\rightarrow$ chén lì (晨礼).

(34) rì piān (日偏) $\rightarrow$ shăng lù (晌礼).

(35) sā shī ní (撒失尼), the second daily prayer = Sino-Persian transcription of يشين; see also $\rightarrow$ shăng lü (晌礼).

(36) shā mù (沙目), the fourth daily prayer = Sino-Persian transcription of شام; see also $\rightarrow h \bar{u} n$ lù (昏礼).

(37) shăng lŭ (晌礼) 'after 12:0o' rì piān (日偏), (șalāt) az-zuhr (الظهر), the second daily prayer ('prayer after twelve o'clock'); see also $\rightarrow$ sā shī ní (撒失尼).

(38) shàng wŭ bài (上午拜), șalāt aḍ-ḍha (صلاة الضحى), is a supererogatory morning prayer (duha means early morning, mid-morning, or even late morning).

(39) shèng xíng bài (圣行拜), Sunnah prayer (صلاة السنة) - an optional prayer that can be performed by Muslims at almost any time of the day.

(40) tài lā wēi hái (泰啦威孩), prayers performed in the nights of the month of Ramaḍān = Sino-Arabic transcription of Arabic tarāwīh (تراويح) id.

(41) wàng yuè lóu (望月楼), jiào bài lóu (叫拜楼), xuān ľ̀ tă (宣礼塔) mìn ā lā bó (敏 阿拉伯) 'minaret'; the last one is a Sino-Arabic transcription (< Arabic منارة id.). The terms jiào bài lóu (叫拜楼) and xuān lì tă (宣礼塔) are not widely known and used. They seem to point merely to the architecture. Not all Hui Muslim mosques have minarets in a common understanding. Some (especially in small villages) have elevated symbols of towers only. In big towns of today's China the use of the minarets for the traditional call for prayer is not permitted - officially because of "noise pollution". Already in 2017 loudspeakers for prayer calls were banned (e.g. in Qīnghǎi) (Yusha, Siqi 2017). The Imāms (Chin. āhōng 阿言 > Pers. آخوند - $\bar{a} \underline{k} \bar{u} n d ~ \sim \bar{a} \underline{k} \bar{o} n d)^{6}$ of the most communities claim that the

6 On this title see Knüppel (2020). 
minarets are observatories to observe the moon during Ramaḍann only and were never used for other purposes. Indeed this is and was one function of the minarets, but the explanations have a direct relation to the ban of public prayer calls which is denied by the Āhōngs and members of their respective communities, even though some "minarets" still have loudspeakers though not in use today. Besides this, the prayer calls in many places are performed publicly (mostly from a record).

(42) xiāo lŭ (宵礼) 'after the sunset' - (șalāt) al-ciš $\bar{a}^{\prime}$ (العشاء) 'the fifth daily prayer' ('prayer after the sunset'); see also $\rightarrow$ hú fūtān (湖夫滩) hŭ fū nán (虎夫难).

(43) xuān jiăng tái (宣讲台) mìn bài ěr (敏拜尔) 'minbar', Sino-Arabic transcription of minbar (منبر), that can be in Hui Muslim mosques either an elevated and rich decorated podium with a roof, or three or four simple wooden steps resembeling a ladder and symbolizing a minbar only.

(44) xuān lü cí (宣礼词) bān kè (班克) 'preaching, sermon'. For this again we have two terms. On the one hand, an alleged Sino-Arabic form, on the other hand, the Chinese term coined for this. The preaching is performed in Arabic language only. According to the Āhōngs bān kè (班克) is borrowed from Arabic, but no corresponding Arabic form could be either given by them or found by the author. Should it be somehow related to baniqqa "originally a silk scarf in which all ministers coming to the Council carried their documents" (Colin 1986)?

(45) xuān lì tă (宣礼塔) $\rightarrow$ wàng yuè lóu (望月楼).

(46) xū qiú bài (需求拜), șalāt al-istihārah (صلاة (صالاستخارة), prayer performed in necessity of guidance on any issue in life.

(47) yè jiān bài (夜间拜), tahağud prayer (هجد), this is performed in the night after the first going to sleep for a while in the evening.

(48) yè jiān lì (夜间礼) $\rightarrow$ jì shù bài (奇数拜).

(49) zàn zhŭ qīng dān (赞主清单), the formula subhāna wa ta'āla (سبحانه و تعلى) ‘Glory to Him, the Exalted'.

(50) zhŭ má (主麻) 'Friday prayer', this is a Sino-Arabic transcription of (salāt) jumu'ah (مع)) id. and the commonly used term (as abbreviation of zhŭ má bàilı̌ [主麻拜礼], zhŭ má jùlı̌ [主麻聚礼], and zhǔ má rì jù lù [主麻日聚礼]).

(51) zhŭ má bàiľ (主麻拜礼) $\rightarrow$ zhŭ má (主麻).

(52) zhŭ má jùlù (主麻聚礼) $\rightarrow$ zhŭ má (主麻).

(53) zhǔ má rì jù lì (主麻日聚礼) $\rightarrow$ zhŭ má (主麻).

(54) zhŭ ming bài (主命拜) = fard prayer (فرض), the five obligatory daily ritual prayers.

Some important further terminology from the context of prayer and performing prayers (such as tašahhud [تشهد], șalāt al-janāzah [صلاة الجنازة], șalāt al-nafl [صلاة نفل],

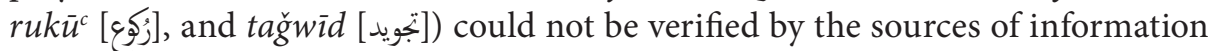
because of the circumstances of fieldwork and therefore it will be dealt with later. 
III.

Key (systematically arranged nos.)

1. (Type of) prayer: 24

1.1. (Daily) ritual prayers: $2,4,5,7,8,10,11,14,15,16,20,33,34,37,42,50,51,52,53,54$

1.2. Supererogatory prayers: $20,31,32,38,39,47,48$

1.3. Communal mandatory prayers: 27

1.4. Congregational prayers: 18,40

1.5. Prayers for special purposes: $9,23,27,31,32,40,46$

2. Components of prayer / prayer unit: $1,6,21,49$

3. Mosque: $3,12,13,17,19,25,26,28,29,30,41,43,44,45$

4. Prayer call: 22

\section{References}

Colin G.S. 1986. Banīḳa. - EI [new edition, vol. 1]: coll. 1016 a-b.

Knüppel M. 2020. On Chinese Āhōng 阿言. - Studia Linguistica Universitatis Iagellonicae Cracoviensis 137: 83-84.

Yusha Z., Siqi C. 2017. Loudspeakers from mosques removed in Qinghai to eliminate noise. Global Times [published: 2017/8/21 23:03:40; http://www.globaltimes.cn/content/1062477. shtml; retrieved: 6.11.2019]. 